\title{
Sleep Related Eating Disorder
}

National Cancer Institute

\section{Source}

National Cancer Institute. Sleep Related Eating Disorder. NCI Thesaurus. Code C118188.

Eating during sleep. 